\title{
The political economy of immigration and welfare state effort: evidence from Europe
}

\author{
Clare Fenwick (iD \\ Department of Economics, Leiden University, Leiden, The Netherlands \\ E-mail: c.e.fenwick@law.leidenuniv.nl
}

(Received 10 December 2018; revised 18 June 2019; accepted 26 June 2019; first published online 20 August 2019)

\begin{abstract}
This article explores whether immigration plays a role in determining national welfare state effort in 16 European countries. It examines the relationship between stocks of migrants, the foreign-born population, on two different indicators of welfare state effort - social welfare spending as a percentage of gross domestic product (GDP) and a welfare generosity index. The nexus between immigration and welfare is a controversial and highly sensitive political issue, and as such it typically divides opinion. Traditionally, it has been argued that increases in immigration create pressures for governments to reduce levels of social welfare provision. By building on theories and results from the political economy literature, this article provides further evidence on the debate through using a fresh approach to operationalize welfare state effort. The empirical results show that the foreign-born population has a positive and statistically significant relationship with social welfare spending and no statistically significant association with the welfare generosity index. The findings provide no evidence to support the hypothesis that the higher levels of immigration lead to reduced levels of social welfare provision. On the contrary, these findings lend support to the view that increasing immigration leads to welfare state expansion rather than retrenchment, and that European welfare states remain resilient in the face of the globalization of migration.
\end{abstract}

Keywords: social protection; welfare state; immigration; Europe

\section{Introduction}

Milton Friedman famously once said 'You cannot simultaneously have free immigration and a welfare state' (1999). He argued that a country with open borders and access to generous welfare provisions would become a haven for poorer migrants which would place a significant fiscal burden on the host country. Consequently, increasing immigration may present serious challenges to Europe's relatively generous welfare states by exposing tensions between the inherently closed system of the welfare state and the relatively open economies of the developed nations. Indeed, some authors have gone so far as to argue that increasing immigration in Europe will eventually lead to the Americanization of European welfare states and politics (Alesina et al., 2001; Alesina and Glaeser, 2004).

On the other hand, current empirical evidence on the topic in Europe is mixed (Soroka et al., 2006; Nannestad, 2007; Lipsmeyer and Zhu, 2011; Stichnoth and Van der Straeten, 2013). In the political economy literature, there are two key competing theories that attempt to explain how immigration, or globalization more generally, may affect national welfare states. They are known as the efficiency hypothesis and the compensation hypothesis. The former is linked to the arguments above and argues that increasing globalization will alter the supply-side of social 
protection through forcing governments to retrench social protection schemes in order to stay globally competitive and reduce the fiscal burden of migrants (Gaston and Rajaguru, 2013). The latter argument focusses on how the demand-side for social protection is altered by globalization, leaving governments in open economies no choice but to expand the welfare state in order to insure citizens against the risks posed by globalization, such as the job insecurity brought about by increased labour migration (Walter, 2010).

In light of these arguments, this article fits within a larger theoretical debate regarding the influence of globalization and growing economic openness on national welfare states in Europe, in particular concerning the increasing movement of people. This article extends previous research (Soroka et al., 2006; Lipsmeyer and Zhu, 2011; Gaston and Rajaguru, 2013; Soroka et al., 2016) by taking into account the arguments from Scruggs and Allan (2006) and Starke (2006) that studies researching welfare policy change should complement expenditure data with additional quantitative measures. Social spending only provides one dimension of welfare state effort, the size of the budget, and so this article augments social spending data with the welfare generosity index developed by Scruggs et al. (2014). Through the use of both indicators, this article contributes to the ongoing dichotomy by illustrating that there is a lack of evidence to support the conclusion that increasing immigration is detrimental to or incompatible with European welfare states. Alternatively, increasing immigration may lead policymakers to actually increase welfare state effort.

For the analysis, pooled time-series cross-sectional analysis is used to explore the association between stocks of migrants, the foreign-born population, on the two different indicators for welfare state effort, social welfare spending as a percentage of gross domestic product (GDP) and the total welfare generosity index. The empirical analysis shows that increases in the foreign-born population are positively and statistically significantly associated with social welfare spending, while there is no significant relationship with the generosity index. The results survive a number of robustness checks and provide no evidence for the efficiency hypothesis. Instead, the findings are in line with researchers who argue that the compensation hypothesis is the prevailing mechanism between globalization and welfare state effort (Burgoon, 2001; Walter, 2010; Gaston and Rajaguru, 2013).

In the following section, the political economy literature surrounding immigration and welfare state effort in the context of globalization is examined. This section includes the formulation of hypotheses on immigration's role in the retrenchment or expansion of the welfare state. The next section focusses on the research design and contains the data and method used to approach the research question. The results and a discussion are presented in the succeeding section, which is followed by a sensitivity analysis. Finally, the last section presents the conclusions and suggests areas for future research.

\section{Literature review and hypotheses}

\section{The theoretical relationship between immigration and the welfare state}

In 1981, Meltzer and Richard developed a political economy model to express how demand for redistribution by voters is dependent on the levels of economic inequality. Assuming voters act rationally and with economic self-interest, the model predicts that when mean income rises relative to median income, those with an income lower than the median will choose candidates who favour higher taxes and greater redistribution - thus taxes will rise and redistribution will increase, and vice versa (Meltzer and Richard, 1981). Magni-Berton (2014) builds on this model to illustrate how immigration reduces demand for redistribution through closing the gap between the mean and median income. The model demonstrates that while low-skilled immigrants lower the mean income of the entire population, an absence of voting rights means the income level of the median voter stays the same. This suggests that in light of increasing immigration, in particular low-skilled immigration, voters would prefer lower taxes and less redistribution. In practice, 
however, voters do not always act rationally and when casting votes individuals must choose between policy bundles and therefore may vote on a preference for reduced immigration rather than a preference for reduced spending.

Razin et al. (2002) also use political economy theory to show how immigration can lead to preferences for lower taxes and less redistribution. They argue that as the foreign-born population increases, a larger proportion of tax revenues go to low-skilled migrants, thus redistribution becomes costlier for the native-born population. As a result, this 'fiscal leakage' from native to immigrant population leads to a shift in attitudes where the median voter will now support lower taxes. However, this relies on the assumption that immigrants are a net drain on public expenditures, of which the evidence is mixed (Boeri, 2010). Following the same logic means that if immigrants are net contributors, then the median voter would shift in favour of increasing welfare state effort (Gaston and Rajaguru, 2013).

In 1982, Ruggie presented an alternative explanation regarding increasing openness and welfare state effort. He proposed that in order to maintain an open international economic order, governments would have to deliver a level of social protection that safeguards citizens from the risks brought by internationalization (Ruggie, 1982). While Ruggie's theory of 'Embedded Liberalism' was intended for the globalization of trade and capital, it is generalizable to the globalization of labour. If immigration is perceived as an economic risk by natives and those who benefit from open borders wish to maintain support for immigration, then the same deal meant for trade and capital could be struck for immigration. Similarly, the compensation hypothesis argues that in light of increasing economic insecurity, natives will demand greater compensation and these policy preferences will shape the response from political elites (Walter, 2010, 2017). There is considerable research supporting the idea that an individual's economic situation strongly affects their policy preferences (Hays et al., 2005), providing the theoretical micro-foundations for the expansion of the welfare state in light of increasing immigration.

\section{The empirical relationship between immigration and the welfare state}

Despite the importance of the subject, remarkably few studies have empirically examined immigration and its role in shaping contemporary welfare state effort. There is, however, significant research on immigration and welfare preferences ${ }^{1}$ that may provide an indication regarding what to expect for welfare effort in Europe. In a study comparing 21 European countries, Finseraas (2008) finds evidence to support opposing effects of immigration on welfare attitudes depending on the risk perceived from immigration. The results presented show that those who are opposed to equal rights for immigrants are less likely to support redistribution, whereas those who believe that immigration reduces average wages or immigrants take jobs away are more likely to support redistribution. Moreover, through analysing survey data from 17 European countries, Burgoon et al. (2012) report that exposure to increasing immigration at the occupational level raises individual economic uncertainties and leads to greater support for government redistribution.

In contrast, Alesina et al. (2001) argue that ethnic diversity is a crucial factor for explaining why the US does not have a welfare state similar to those in Europe. They find that if the probability of two people drawn at random from a population will belong to different ethnic groups increases by just one percentage point, then social spending as a percentage of GDP is expected to reduce by 7.5 percentage points. Consequently, they reason that as Europe's heterogeneity increases, rising ethnic divisions will be used to challenge generous welfare states. Alesina and Glaeser (2004) extend their previous research through expanding their analysis to 54 countries worldwide. They find a negative correlation between ethnic fractionalization and social spending. They propose that generous welfare states are contingent on a homogeneous society because support for the welfare state depends on solidarity between citizens which is fostered through common linkages

\footnotetext{
${ }^{1}$ See Stichnoth and Van der Straeten (2013) for a review of the empirical literature.
} 
such as culture and language. Alesina and Glaeser (2004) state that increasing immigration in Europe will challenge Europe's comparatively generous welfare states.

Soroka et al. (2006) combine two Organization for Economic Co-operation and Development (OECD) social spending databases covering 18 OECD countries over the period 1960-2000. They investigate changes in stocks of foreign-born on changes in social welfare spending and show that in countries with higher rates of immigration, welfare spending grows less than in countries with limited migration. Soroka et al. (2016) build on this previous research through separating social spending into nine different sub-categories and find that there are different effects in different spending programmes and provide further evidence for their assertion that increases in immigration lead to smaller increases in social welfare spending. In a qualitative study looking specifically at the EU, Kvist (2004) examines whether EU enlargement leads to member states adjusting their social policy benefits. He argues that EU-15 member states do engage in strategic interactions and that the member states most actively adjusting their social policies are the ones that put in place fewer restrictions on the labour market access of citizens from new member states. In light of recent EU enlargements, it is possible that these interactions may have continued.

However, using a sample of European OECD Countries in a quantitative study, Mau and Burkhardt (2009) contend the conclusion that migration poses a threat to European welfare states. They reason that the claim is over-exaggerated and show only a weak, negative influence of ethnic diversity on support for the welfare state, which is mediated when controlling for certain factors such as GDP and unemployment. Moreover, in a comparative study across 15 European countries from 1971 to 2007, Lipsmeyer and Zhu (2011) find that domestic political pressures, such as the strength of left parties and trade unions, can mediate the relationship between unemployment compensation and migration. Using changes in net migration and levels of unemployment replacement rates, they show that when labour unions are strong and left parties hold more parliamentary seats, then higher net migration rates are associated with higher levels of benefits. Finally, using data on levels of social expenditures and the foreign-born population for 25 OECD countries for the years 1980-2008, Gaston and Rajaguru (2013) find no negative relationship between migration and social spending in a sample. Instead, they determine that depending on the countries included in the sample, immigration can have a positive effect on social welfare spending.

As evidenced by the mixed results and conclusions in the literature, the association between immigration and welfare state effort is complex and likely to be influenced and mediated by a number of factors. It is entirely possible that immigration creates opposing pressures on the welfare state and that one effect may simply dominate over another. As the analysis takes into account two dependent variables, which represent two different operationalizations of welfare state effort, then different effects may materialize. This could be a result of substantive reasons such as the inclusion of different programmes in each aggregate indicator. Nonetheless, it would be surprising to find completely opposing effects in the two indicators.

\section{Hypotheses}

This analysis is based on a European sample, subsequently it is possible that a higher proportion of immigrants are low-skilled and work in lower-paid jobs (UN-DESA and OECD 2013), in which case the theoretical models would predict that increasing immigration leads to reductions in welfare state effort. The empirical work of Alesina et al. (2001), Alesina and Glaeser (2004), and Soroka et al. $(2006,2016)$ would generally support this. On the other hand, should those immigrants increase perceptions of economic risk for the native labour force through increasing the competitiveness of the labour market, then increasing immigration could alternatively lead to increases in welfare state effort. The recent empirical results from Gaston and Rajaguru (2013) and Lipsmeyer and Zhu (2011) lean towards this expectation. Considering the literature and the competing mechanisms, two hypotheses are proposed: 
HYPOTHESIS 1: Retrenchment: increasing immigration is associated with reductions in welfare state effort - reflected in decreases in spending and/or generosity.

HYPOTHESIS 2: Expansion: increasing immigration is associated with increases in welfare state effort - reflected in increases in spending and/or generosity.

\section{Research design: data and methods}

To test the hypotheses, data spanning 16 European countries ${ }^{2}$ for the years 1990-2010 has been collected. The countries in the sample chosen are European countries in the OECD because the more economically developed European countries simultaneously tend to be typical migrant destinations and the ones with traditional, advanced welfare states. However, some European OECD countries are excluded ${ }^{3}$ despite accessible spending data as no 'total generosity' measure is available for these countries in the Comparative Welfare Entitlements Dataset (CWED). For our two dependent variables - social spending and the generosity index - the aggregate measures are used. While this can mask programme-specific changes, it provides a useful overview of general associations which has yet to be done in this specific context for the generosity index.

\section{Dependent variable: operationalizing welfare state effort}

The commonly used indicator to depict welfare state effort is social spending as a percentage of GDP (Allan and Scruggs, 2004). There are clear advantages to this measure - it provides a good indication of the overall generosity of a welfare state as it captures the size of the budget, there is no need to correct for inflation and exchanges rates, and it is well recorded so data is readily available for most European countries over an extended period of time. However, this measure has been criticized for a number of reasons, such as not adequately capturing changes in legislation regarding entitlement criteria, coverage, and duration (Scruggs, 2007). Subsequently, there has been extensive debate over spending's suitability as an indicator of welfare state effort because it may not adequately reflect policy change (Allan and Scruggs, 2004; Green-Pedersen 2004; Starke 2006; Clasen and Siegel, 2007; Caminada et al., 2010; Jensen, 2011; van Oorschot, 2013; Wang and van Vliet, 2016).

To take into account the 'dependent variable problem', this article uses two different indicators to explore how immigration influences welfare state effort. As is common convention, social welfare spending as a percentage of GDP from the OECD's Social Expenditure (SOCX) Database (2017c) is used, which is then compared with the welfare generosity index from the CWED developed by Scruggs et al. (2014). ${ }^{4}$ While social spending can sufficiently capture developments in the size of the budget once the appropriate controls for social need are included, the generosity index should be able to better capture other elements of welfare state effort such as changes in entitlement criteria and benefit duration (Scruggs, 2006). However, a limitation of this

\footnotetext{
${ }^{2}$ Austria, Belgium, Denmark, Finland, France, Germany, Greece, Ireland, Italy, Netherlands, Norway, Portugal, Spain, Sweden, Switzerland, and United Kingdom.

${ }^{3}$ Czech Republic, Estonia, Hungary, Latvia, Lithuania, Poland, Slovakia, and Slovenia.

${ }^{4}$ The welfare generosity index from the CWED contains information on the generosity of social benefits through combing data on benefit replacement rates, qualifying conditions and benefit duration, and elements of insurance coverage/take-up rates. It covers unemployment insurance, sick pay insurance, and public pensions. Unemployment insurance only covers national insurance provisions that are earned without income testing and it excludes programmes such as the UK's income-based Jobseeker's Allowance or Germany's unemployment assistance. Sick pay insurance covers the benefits that are paid in the instance of short-term non-occupational illness or injury. Public pensions covers only mandatory public programmes (Scruggs et al. 2014) The index closely resembles Esping-Andersen's 'decommodification index' in The Three Worlds of Welfare Capitalism (Scruggs and Allan 2006; Esping-Andersen 1990).
} 
Table 1. Social welfare spending as a percentage of GDP

\begin{tabular}{lclclr}
\hline Country & Mean & \multicolumn{1}{c}{ Country } & Mean & \multicolumn{1}{c}{ Country } & Mean \\
\hline France & 29 & Luxembourg & 22 & Czech Republic & 18 \\
Sweden & 28 & Spain & 22 & Switzerland & 17 \\
Finland & 27 & Hungary & 22 & Slovakia & 17 \\
Belgium & 26 & Greece & 20 & Ireland & 17 \\
Austria & 26 & Netherlands & 21 & Iceland & 15 \\
Denmark & 26 & Poland & 21 & Estonia & 15 \\
Germany & 25 & Slovenia & 21 & & \\
Italy & 24 & Portugal & 20 & & \\
Norway & 22 & United Kingdom & 19 & & \\
& & & & Average & \\
\hline
\end{tabular}

Table 2. Total generosity index

\begin{tabular}{lclclr}
\hline Country & Mean & Country & Mean & Country & Mean \\
\hline Norway & 42 & Denmark & 36 & Portugal & 31 \\
Belgium & 41 & Finland & 35 & Italy & 28 \\
Sweden & 41 & Germany & 35 & Greece & 28 \\
France & 38 & Spain & 34 & United Kingdom & 27 \\
Netherlands & 37 & Austria & 33 & & \\
Switzerland & 36 & Ireland & 31 & & 35 \\
& & & & Average & \\
\hline
\end{tabular}

index is the exclusion of particular social protection programmes - such as certain types of unemployment schemes, maternity leave benefits, child/family benefits, and publicly provided health insurance/universal healthcare. Furthermore, the generosity index does not solve problems such as the 'gradual manifestation' of policy decisions in welfare state effort and concerns about the reliability of data. ${ }^{5}$

Table 1 shows social spending as an average over the period 1990-2015 for each country. ${ }^{6}$ France tops the table with an average 29 percent of its GDP spent on social welfare. Unsurprisingly, the Scandinavian countries also have high levels of social spending. Notably, however, Norway is somewhat lower with 22 percent of its GDP spent on social welfare on average this could be because Norway spends considerably less on pensions, which usually make up a large proportion of social expenditures. Overall, it appears that Western European countries have higher levels of social spending than Eastern or Southern European countries, which links to the welfare state typologies developed by Esping-Andersen (1990). Overall, Social Democratic and Conservative welfare state typologies dominate the top half of the table and in contrast, the post-Soviet and Liberal welfare states spend a much lower percentage of GDP on welfare. When social spending is compared to the Welfare Generosity Index in Table 2, we can see that they do not exactly correspond (the correlation is 0.4). Interestingly, Norway leaps from ninth place to first - it is possible that because Norway is a particularly rich country, it can spend relatively less on social welfare while still maintaining the generosity of its benefits.

\footnotetext{
${ }^{5}$ Spending is measured as a percentage of GDP and the average production worker wage is used for the replacement rates in the construction of the generosity index. Thus, these indicators can change because GDP grows, or average wages increase rather than because of an actual change in the generosity of a benefit.

${ }^{6}$ There is a different set of countries and a longer time period covered in Table 1 than in the main sample as the OECD provides more data than the CWED. In the sensitivity analysis for spending, the sample in the IV model is expanded to include the additional European countries and the most recent years.
} 
Table 3. Foreign-born as a percentage of the total population

\begin{tabular}{lclclr}
\hline Country & Mean & \multicolumn{1}{c}{ Country } & Mean & Country & Mean \\
\hline Luxembourg & 36 & France & 11 & Norway & 9 \\
Switzerland & 24 & Slovenia & 11 & Portugal & 7 \\
Estonia & 17 & Spain & 10 & Czech Republic & 6 \\
Austria & 14 & Greece & 10 & Denmark & 6 \\
Ireland & 13 & Netherlands & 10 & Finland & 4 \\
Belgium & 12 & Iceland & 9 & Slovakia & 4 \\
Germany & 12 & Italy & 9 & Hungary & 3 \\
Sweden & 12 & United Kingdom & 9 & Poland & 2 \\
& & & & Average & 11 \\
\hline
\end{tabular}

\section{Explanatory variable}

Following the example of previous researchers (Soroka et al., 2006; Mau and Burkhardt 2009; Gaston and Rajaguru 2013), the main explanatory variable is foreign-born as a percentage of the population (OECD 2017a), which serves as an indicator of the stock of migrants in a country. The standard definition of foreign-born is 'all persons who have ever migrated from their country of birth to their current country of residence' (OECD 2017a). Table 3 displays the average foreignborn population in 24 European countries between 1990 and 2015. ${ }^{7}$ To start, there is a considerable variation. As expected, countries that are typically considered countries of immigration such as Sweden, Germany, and Austria have high foreign-born populations. Luxembourg and Switzerland are exceptional, with high numbers of EU workers in particular. Countries traditionally considered countries of emigration, such as Poland, have on average smaller foreign-born populations. Estonia's high foreign-born population is somewhat of an outlier. It is high because of the large number of recognized non-citizens - they are mainly former Soviet-Union citizens who are permanent residents, but have not acquired any other citizenship (Eurostat, 2017b).

\section{Control variables}

In this section, the control variables are discussed. They cover population demographics, domestic economic conditions, political institutions, economic globalization, and deindustrialization. The variables are all drawn from the previous, relevant empirical literature (Soroka et al., 2006; Lipsmeyer and Zhu, 2011; Gaston and Rajaguru, 2013; Soroka et al., 2016).

Population demographics: Certain population demographics are controlled for by including the population under 15 and the population over 64 in the model specification (OECD 2017b). It is reasonable to assume that spending increases as a larger proportion of the population becomes dependent on working age tax payers (Soroka et al., 2006).

Economic controls: The effect that a country's domestic economic status may have on welfare state effort is controlled for using three key variables: GDP growth, the national unemployment rate, and female labour force participation. First, Gaston and Rajaguru (2013) find that GDP growth has a significant and negative association with social spending because 'this reflects the fact that the denominator (GDP) grows more slowly than the numerator (SOCX) when the economy slows' (2013, p. 95). For generosity, as the index is not constructed as a proportion of GDP, the effect may be different. Second, the unemployment rate is included as a control for the domestic labour market (OECD, 2017b). Higher unemployment would indicate more spending on unemployment benefits, but the fiscal cost may put pressure on generosity. Third, female labour

\footnotetext{
${ }^{7}$ Over time, most Western European countries have seen a steady increase in their foreign-born populations. For a graphical representation of the changes over time for social spending, the generosity index, and foreign-born see Appendix A.
} 
force participation (OECD, 2017b), which is thought to affect welfare effort through increased public child-care infrastructure to support working mothers.

Political institutions: 'One of the strongest generalizations that can be made about the origins and growth of the welfare state is that where trade unions and social democratic parties are strong, the welfare state has thrived' (Freeman, 1986, p. 61). It is generally thought that left-leaning governments, who traditionally have electoral ties to the working class and unions, will support greater redistribution (Armingeon and Giger, 2008), although the importance of partisan politics is still debated (Pierson, 1996; Starke et al., 2014). Moreover, some authors find that a strong left or strong trade unions can counteract the potential negative effects of diversity on welfare generosity (Taylor-Gooby, 2005; Lipsmeyer and Zhu, 2011). As a result, the ideology of the government in power is controlled for by including the percentage of cabinet posts held by social democratic and other left-wing parties, weighted by the number of days in office in a given year (Armingeon et al., 2017). Additionally, trade union density, measured as net union membership as a share of wage and salary earners in employment, is used as a control for the bargaining power of domestic labour (Visser, 2016).

Economic globalization and deindustrialization: Globalization has been argued to both reduce public spending and increase it (Cerny, 1995; Rodrik, 1998). As Soroka et al. $(2006,2016)$ do not account for globalization in their specification, then the example set by Gaston and Rajaguru (2013) is followed and the KOF economic globalization indicator is used (Dreher, 2006). Conversely, Iversen and Cusack (2000) argue that it is deindustrialization that leads to economic uncertainty and demand for compensation, not globalization. Therefore, deindustrialization is also accounted for.

\section{Method and model specification}

This article uses pooled time-series cross-sectional analysis - a common practice is to use the de facto Beck-Katz standard, which combines fixed effects with a lagged dependent variable (Soroka et al., 2006; Lipsmeyer and Zhu, 2011; Gaston and Rajaguru, 2013; Soroka et al., 2016). However, the lagged dependent variable can be a considerable source of bias, known as Nickell bias (Nickell, 1981), as it is highly correlated with the dependent variable and thus causes an upward bias in the standard errors. Subsequently, the estimation model does not provide an accurate coefficient for the key explanatory variable. Accordingly, panel-corrected standard errors with the PraisWinsten correction for serial correlation - argued for as more appropriate by Plümper et al. (2005) - are used for the analysis. The main model specification is presented in levels, as a change from year to year is not as drastic as a 5-year change, such as Soroka et al. (2016) use in their analysis. Hence, the overall volume (level) of migration from year to year may be more noticeable to natives. Notably, when testing the dependent variables for stationarity, a number of panels have a unit root but not all. ${ }^{8}$ As a result, a model using changes is included as a robustness check.

The explanatory variable and all controls are lagged by 1 year - Gaston and Rajaguru (2013) do the same, while Lipsmeyer and Zhu (2011) and Soroka et al. $(2006,2016)$ lag a selection. The reasoning is that in the case of certain variables, it makes theoretical sense - policy decisions can take time to be reflected in spending levels. Plus, lagging can help mitigate endogeneity issues arising from reverse causality. However, as reverse causality is an important methodological consideration, ${ }^{9}$ an instrumental variable regression using lags of foreign-born as instruments is provided as an additional robustness check.

Finally, country fixed effects are used in order to account for cross-sectional heterogeneity of the intercepts and omitted variable bias. By using country fixed effects, the aim is to ensure that

\footnotetext{
${ }^{8}$ Appendix B provides the $P$-values for each panel and both dependent variables.

${ }^{9}$ To test for possible reverse causality, the lagged level of spending was regressed on the level of foreign-born and a positive statistically significant relationship was found. No such relationship was found for changes.
} 
Table 4. Results for the main model specification, spending and generosity

\begin{tabular}{|c|c|c|}
\hline Variable & $\begin{array}{c}(1) \\
\text { Spending }\end{array}$ & $\begin{array}{c}\text { (2) } \\
\text { Generosity } \\
\end{array}$ \\
\hline Foreign-born $_{t-1}$ & $\begin{array}{l}0.272^{\star \star \star} \\
(0.102)\end{array}$ & $\begin{array}{c}0.050 \\
(0.074)\end{array}$ \\
\hline Population under $15_{t-1}$ & $\begin{array}{l}0.596^{\star \star \star} \\
(0.219)\end{array}$ & $\begin{array}{l}-0.184 \\
(0.215)\end{array}$ \\
\hline Population over $64_{t-1}$ & $\begin{array}{l}0.378^{*} \\
(0.199)\end{array}$ & $\begin{array}{l}-0.202 \\
(0.134)\end{array}$ \\
\hline 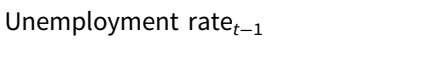 & $\begin{array}{l}0.129^{*} \\
(0.072)\end{array}$ & $\begin{array}{l}-0.047 \\
(0.051)\end{array}$ \\
\hline 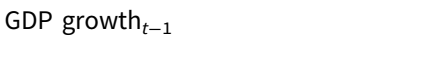 & $\begin{array}{c}-0.234^{\star \star \star} \\
(0.084)\end{array}$ & $\begin{array}{l}-0.006 \\
(0.021)\end{array}$ \\
\hline Female labour force participation ${ }_{t-1}$ & $\begin{array}{l}0.222^{\star \star \star} \\
(0.074)\end{array}$ & $\begin{array}{l}0.249^{* * \star} \\
(0.050)\end{array}$ \\
\hline Left seats $_{t-1}$ & $\begin{array}{c}0.002 \\
(0.003)\end{array}$ & $\begin{array}{c}0.003 \\
(0.002)\end{array}$ \\
\hline Union density ${ }_{t-1}$ & $\begin{array}{c}0.063 \\
(0.050)\end{array}$ & $\begin{array}{l}0.187^{\star \star \star} \\
(0.044)\end{array}$ \\
\hline KOF - economic $c_{t-1}$ & $\begin{array}{c}0.002 \\
(0.067)\end{array}$ & $\begin{array}{l}-0.013 \\
(0.027)\end{array}$ \\
\hline Deindustrialization $_{t-1}$ & $\begin{array}{c}0.022 \\
(0.101)\end{array}$ & $\begin{array}{c}0.034 \\
(0.086)\end{array}$ \\
\hline Intercept & $\begin{array}{c}-8.664 \\
(10.788)\end{array}$ & $\begin{array}{l}18.799^{*} \\
(9.809)\end{array}$ \\
\hline Country dummies & Yes & Yes \\
\hline Year dummies & No & No \\
\hline$N$ & 196 & 196 \\
\hline $\operatorname{Adj} R^{2}$ & 0.914 & 0.982 \\
\hline Rho & 0.340 & 0.617 \\
\hline
\end{tabular}

Standard errors in parentheses.

${ }^{*} P<.1,{ }^{* *} P<.05,{ }^{* * *} P<.01$

time-invariant, country-specific aspects such as cultural influences that influence welfare state effort are accounted for. By doing so, all between-unit variation is eliminated, which narrows the analysis (Mummolo and Peterson, 2018). In addition, external, temporal shocks such as the expansion of the EU and the 2008 financial crisis may affect the results and so a two-way fixed effects model is provided as a robustness check. It is not provided as the main model specification as a two-way fixed effects model makes strong assumptions about pooled time-series cross-sectional datasets and requires a separate interpretation that can be difficult to conceptualize (Kropko and Kubinec, 2018).

\section{Results and discussion}

\section{Welfare state effort}

Table 4 presents the results of social spending and the generosity index in Column 1 and Column 2 , respectively. The estimate in column 1 of Table 4 indicates that higher levels of foreign-born are positively and significantly associated with higher levels of social spending, a 1 percentage point increase in foreign-born as a percentage of the population over time is associated with a 0.27 percentage point increase in social welfare spending as a percentage of GDP. The estimate in column 
2 of Table 4 shows that the relationship between the foreign-born population and the generosity index is not statistically different from zero.

The results point to possible expansion of the welfare state in light of increasing migration. With regard to the mechanism, other studies have shown that exposure to globalization increases individual risk, especially for low-skilled workers' perceived labour market risks (Walter, 2010, 2017). Moreover, research that has focussed on immigration and welfare preferences have shown that if natives feel economically insecure when exposed to increasing movement of labour, particularly at an occupational level, then they support more compensation and greater redistribution from the government (Finseraas, 2008; Burgoon et al., 2012). The results in this article suggest that this may be reflected in voter preferences, and for vote-seeking politicians, voter demand could outweigh budgetary pressure (stemming from increased global competition) to cut taxes and reduce the supply-side of social welfare.

Nevertheless, it is important to note that instead of the increase in spending indicating support for the compensation hypothesis, spending may increase because the foreign-born population costs the welfare state more in terms of unemployment or child-care costs (Boeri, 2010) rather than increased generosity. On the other hand, as the foreign-born population in the EU is, on average, younger than the native population and less likely to use the health system or draw a pension (Eurostat, 2017a) then migrant dependence may not be a cause for concern. Moreover, should European welfare states be experiencing fiscal pressure from increasing immigration, then it would be reasonable to expect that the generosity indicator would be negative and statistically significant in light of the arguments of the efficiency hypothesis - dependent migrants lead to fiscal pressure and the need to reduce welfare state effort. Just as social spending is a flawed indicator, so is the welfare generosity index, and consequently the lack of a statistically significant relationship between foreign-born and the welfare generosity index does not mean that the increase in social spending is not indicative of increasing generosity. Thus, the results provide no evidence for the first hypothesis proposed - that increasing immigration leads to welfare state retrenchment. In contrast, the findings lend support to the alternative hypothesis that increasing immigration leads to welfare state expansion.

Differing effects between spending and generosity are also found for a number of the control variables. The size of the population over 64 years old has a significant and positive impact on social spending as the number of beneficiaries will be an important predictor of spending, especially considering spending on pensions usually takes up a large proportion of overall public spending. However, there is no statistically significant effect of the population over 64 on the generosity index, likewise for those under the age of 15 and for the unemployment rate. The results show that, as expected, GDP growth is significant and negatively associated with social spending as in an economic downturn, the denominator (GDP) will grow more slowly than the numerator (social spending), while for the generosity index, there is no statistically significant relationship with GDP growth.

Female labour force participation has a positive and statistically significant effect on both spending and the generosity index. It is likely that female labour force participation increases welfare state effort through the need for improved child-care infrastructure. Soroka et al. (2016) also suggest that increased spending may be linked to increased costs from supporting a larger work force (e.g. training, insurance, and leave). Furthermore, the findings indicate that union membership and support may be more important for determining welfare state effort than the strength of left parties. Union density is positively and significantly associated with the generosity index, while the proportion of left cabinet seats is not significantly associated with either indicator. For unions, the difference in results is quite likely to be related to the programmes that are included in the generosity index; pensions, sickness, and unemployment benefits are closely linked to labour market participation and tend to insure workers from labour market risks. Plus, this is similar to the results found by Lipsmeyer and Zhu (2011) who argue that domestic political pressures are important for explaining higher 
unemployment compensation in an age of increasing immigration. For left cabinet seats, there is considerable debate about the importance of partisan politics on the expansion and retrenchment of the welfare state (Pierson, 1996; Allan and Scruggs, 2004; Rueda, 2006), the results here would support Pierson (1996) and the 'new politics of the welfare state'.

Finally, in contrast to Gaston and Rajaguru (2013) who find a statistically significant, negative relationship between economic globalization and social spending, there is no significant impact of the KOF economic globalization indicator on either social spending or the generosity index. Similarly, in contrast to Iversen and Cusack (2000), there is no significant association between deindustrialization and either social spending or the generosity index.

Overall, the analysis provides no evidence for the first hypothesis proposed - that increasing immigration leads to welfare state retrenchment. Rather, the positive association between foreignborn and spending, and the neutral association between foreign-born and generosity, provide some evidence for the alternative hypothesis - that increasing immigration leads to welfare state expansion, although, the two dependent variables do not show identical outcomes. In order to explain the difference between spending and generosity, it is important to note that they provide slightly different operationalizations of welfare state effort - budget size vs. benefit type and entitlement criteria, and they are constructed in different ways. As a consequence, the differences between the two indicators could be down to modelling or substantive reasons.

In the case of modelling, for example, it may be that for one indicator there is an omitted variable but not for the other, or that the appropriate model specification may be slightly different for each dependent variable. However, the difference is more likely to be the result of a substantive reason, such as the two indicators measure slightly different aspects of welfare state effort. Arguably, the generosity index is a better indicator for policy changes and how politicians aim to redistribute social risk, but it excludes a large number of social programmes such as family benefits, certain types of unemployment insurance, and healthcare. As aggregate indicators have been used, there could be specific programmes driving the changes in spending that are not included within the generosity index. Moreover, the generosity index combines the three welfare programmes it covers equally. For social spending, however, the budget is not equally split between its component programmes and that different weighting could lead to slightly differing effects. Another possibility is that because the generosity index is created through combining replacement rates and benefit rule changes, there could be opposing effects happening on these constituent parts of the indicator leading to a neutral result. Finally, it may be that different mechanisms apply to the different programmes included in the generosity index; hence, the net effect is neutral. An area for future research could be to untangle these different associations for specific programmes outside of spending, which would complement this article and the research conducted by Soroka et al. (2016). Largely, however, neither measure indicates that any retrenchment of the welfare state is taking place as a result of immigration.

\section{Sensitivity analysis}

In order to check the robustness of the results, three main tests were undertaken. First, because of the mixed results regarding panel stationarity, a first-differences model has been estimated in Table 5. Second, Table 6 shows the results of the two-way fixed effects model and third, Table 7 presents the results of an instrumental variable (IV) regression. Overall, the effect of foreign-born on spending and generosity remains stable across the various models employed.

Table 5 shows the results for spending and generosity as a lagged first-differences model. In this model the number of observations drops, and the explanatory power of the model reduces, but the foreign-born population remains statistically significant and positively associated with social spending, while there is still no relationship with the generosity index. Moreover, the magnitude of the coefficient for foreign-born is similar to the original model of lagged levels. Table 6 then shows the original specification but with the inclusion of two-way fixed effects. Again, the results 
Table 5. Results for the first-differences model

\begin{tabular}{|c|c|c|}
\hline Variable & $\begin{array}{c}\text { (1) } \\
\text { Spending }\end{array}$ & $\begin{array}{c}\text { (2) } \\
\text { Generosity }\end{array}$ \\
\hline$\Delta$ Foreign-born $_{t-1}$ & $\begin{array}{l}0.251^{\star} \\
(0.142)\end{array}$ & $\begin{array}{l}-0.014 \\
(0.100)\end{array}$ \\
\hline$\Delta$ Population under $15_{t-1}$ & $\begin{array}{c}0.882 \\
(0.829)\end{array}$ & $\begin{array}{l}-0.209 \\
(0.364)\end{array}$ \\
\hline$\Delta$ Population over $64_{t-1}$ & $\begin{array}{c}0.882 \\
(0.829)\end{array}$ & $\begin{array}{l}-0.209 \\
(0.364)\end{array}$ \\
\hline$\Delta{\text { Unemployment } \text { rate }_{t-1}}$ & $\begin{array}{l}-0.170 \\
(0.142)\end{array}$ & $\begin{array}{l}-0.049 \\
(0.056)\end{array}$ \\
\hline 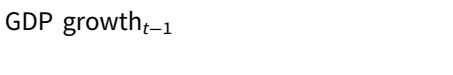 & $\begin{array}{l}-0.047 \\
(0.092)\end{array}$ & $\begin{array}{l}-0.016 \\
(0.023)\end{array}$ \\
\hline$\Delta$ Female labour force participation $_{t-1}$ & $\begin{array}{c}0.272 \\
(0.191)\end{array}$ & $\begin{array}{c}0.126 \\
(0.081)\end{array}$ \\
\hline$\Delta$ Left seats $_{t-1}$ & $\begin{array}{l}-0.002 \\
(0.004)\end{array}$ & $\begin{array}{c}0.002 \\
(0.002)\end{array}$ \\
\hline$\Delta$ Union density $_{t-1}$ & $\begin{array}{c}0.054 \\
(0.055)\end{array}$ & $\begin{array}{l}0.080^{\star} \\
(0.044)\end{array}$ \\
\hline$\Delta \mathrm{KOF}-$ economic $_{t-1}$ & $\begin{array}{l}-0.093 \\
(0.095)\end{array}$ & $\begin{array}{l}-0.025 \\
(0.027)\end{array}$ \\
\hline$\Delta$ Deindustrialization $_{t-1}$ & $\begin{array}{c}0.221 \\
(0.147)\end{array}$ & $\begin{array}{c}0.001 \\
(0.094)\end{array}$ \\
\hline Intercept & $\begin{array}{c}0.140 \\
(0.274)\end{array}$ & $\begin{array}{c}0.058 \\
(0.092)\end{array}$ \\
\hline Country dummies & No & No \\
\hline Year dummies & No & No \\
\hline$N$ & 176 & 176 \\
\hline $\operatorname{Adj} R^{2}$ & 0.069 & -0.019 \\
\hline Rho & 0.032 & 0.107 \\
\hline
\end{tabular}

Standard errors in parentheses.

${ }^{*} P<.1,{ }^{* *} P<.05,{ }^{* * *} P<.01$

for foreign-born hold for both dependent variables, although the magnitude of the effect for social spending reduces.

For Table 7, the instruments that are used are 7- and 8-year lags of the foreign-born population. For an IV regression, it is not uncommon to use earlier years of the independent variable as instruments. The logic is that previous years' levels of the foreign-born population provide a strong predictor of future years' levels of the foreign-born population and thus satisfy the relevance criteria. ${ }^{10}$ Next, the years are considered to be far enough back in time that the levels in those years are highly unlikely to directly influence current levels of social spending and generosity, thus satisfying the exogeneity criteria. ${ }^{11}$ Columns 1 and 2 in Table 7 show the IV regressions for the original model specifications. The results hold, the foreign-born population is positive and statistically significant, while there is no association with the generosity index. The crucial change is that the magnitude of the coefficient for foreign-born is larger.

However, taking lagged levels of the foreign-born variable as instruments means that the number of observations greatly reduces. For spending though, a much larger sample is available as the OECD provides spending and migration data for more European countries over a longer period of time. In the original spending estimation, the sample is restricted to the countries and date range

\footnotetext{
${ }^{10}$ The first stage F-statistic is 43.45 .

${ }^{11}$ The Sargan-Hansen test of over-identifying restrictions confirms the validity of the instruments.
} 
Table 6. Results for the two-way FE model

(1) (2)

\begin{tabular}{|c|c|c|}
\hline Variable & Spending & Generosity \\
\hline Foreign-born $_{t-1}$ & $\begin{array}{l}0.152^{* *} \\
(0.072)\end{array}$ & $\begin{array}{c}0.039 \\
(0.092)\end{array}$ \\
\hline Population under $15_{t-1}$ & $\begin{array}{l}0.555^{\star \star} \\
(0.222)\end{array}$ & $\begin{array}{l}-0.177 \\
(0.297)\end{array}$ \\
\hline Population over $64_{t-1}$ & $\begin{array}{c}0.164 \\
(0.160)\end{array}$ & $\begin{array}{c}-0.214 \\
(0.166)\end{array}$ \\
\hline Unemployment rate $_{t-1}$ & $\begin{array}{l}0.237^{\star \star \star} \\
(0.065)\end{array}$ & $\begin{array}{l}-0.016 \\
(0.099)\end{array}$ \\
\hline GDP growth $_{t-1}$ & $\begin{array}{c}-0.196^{\star \star \star} \\
(0.050)\end{array}$ & $\begin{array}{c}-0.008 \\
(0.054)\end{array}$ \\
\hline Female labour force participation ${ }_{t-1}$ & $\begin{array}{l}0.167^{\star *} \\
(0.071)\end{array}$ & $\begin{array}{l}0.228^{\star \star \star} \\
(0.082)\end{array}$ \\
\hline Left seats $_{t-1}$ & $\begin{array}{l}0.004^{*} \\
(0.002)\end{array}$ & $\begin{array}{c}0.003 \\
(0.003)\end{array}$ \\
\hline Union density $_{t-1}$ & $\begin{array}{l}0.115^{\star \star \star} \\
(0.044)\end{array}$ & $\begin{array}{l}0.217^{\star \star \star} \\
(0.065)\end{array}$ \\
\hline $\mathrm{KOF}-$ economic $_{t-1}$ & $\begin{array}{c}0.064 \\
(0.051)\end{array}$ & $\begin{array}{c}0.006 \\
(0.054)\end{array}$ \\
\hline Deindustrialization $_{t-1}$ & $\begin{array}{c}-0.177^{\star} \\
(0.104)\end{array}$ & $\begin{array}{l}-0.064 \\
(0.200)\end{array}$ \\
\hline Intercept & $\begin{array}{c}4.227 \\
(12.612)\end{array}$ & $\begin{array}{c}22.706 \\
(19.732)\end{array}$ \\
\hline Country dummies & Yes & Yes \\
\hline Year dummies & Yes & Yes \\
\hline$N$ & 196 & 196 \\
\hline $\operatorname{Adj} R^{2}$ & 0.964 & 0.980 \\
\hline Rho & 0.617 & 0.569 \\
\hline
\end{tabular}

Standard errors in parentheses.

${ }^{*} P<.1,{ }^{* *} P<.05,{ }^{\star * *} P<.01$

found in CWED in order to directly compare spending and generosity. Subsequently, for the IV regression, the sample for spending is expanded to include more years in column 3 , and then more countries $^{12}$ in Column 4. This expansion means that the results incorporate observations following the last round of EU enlargement and the last of the labour market restrictions on Bulgarians and Romanians have been lifted. In light of an expanded sample, the results for foreign-born remain statistically significant and positively associated with social welfare spending and provide support to the theory that the globalization of migration is associated with compensatory effects.

\section{Concluding remarks}

This article set out to examine the role that immigration has to play in determining welfare state effort in Europe through empirically testing the relationship between stocks of immigrants, as measured by the proportion of the population that is foreign-born, and welfare state effort, as measured by social welfare spending as percentage of GDP and a welfare generosity index. The results indicate that immigration has a positive impact on welfare state effort. Social welfare spending is positively and significantly associated with foreign-born and when social welfare spending is exchanged for a welfare

\footnotetext{
${ }^{12}$ Czech Republic, Estonia, Hungary, Iceland, and Luxembourg.
} 
Table 7. Results for the IV model

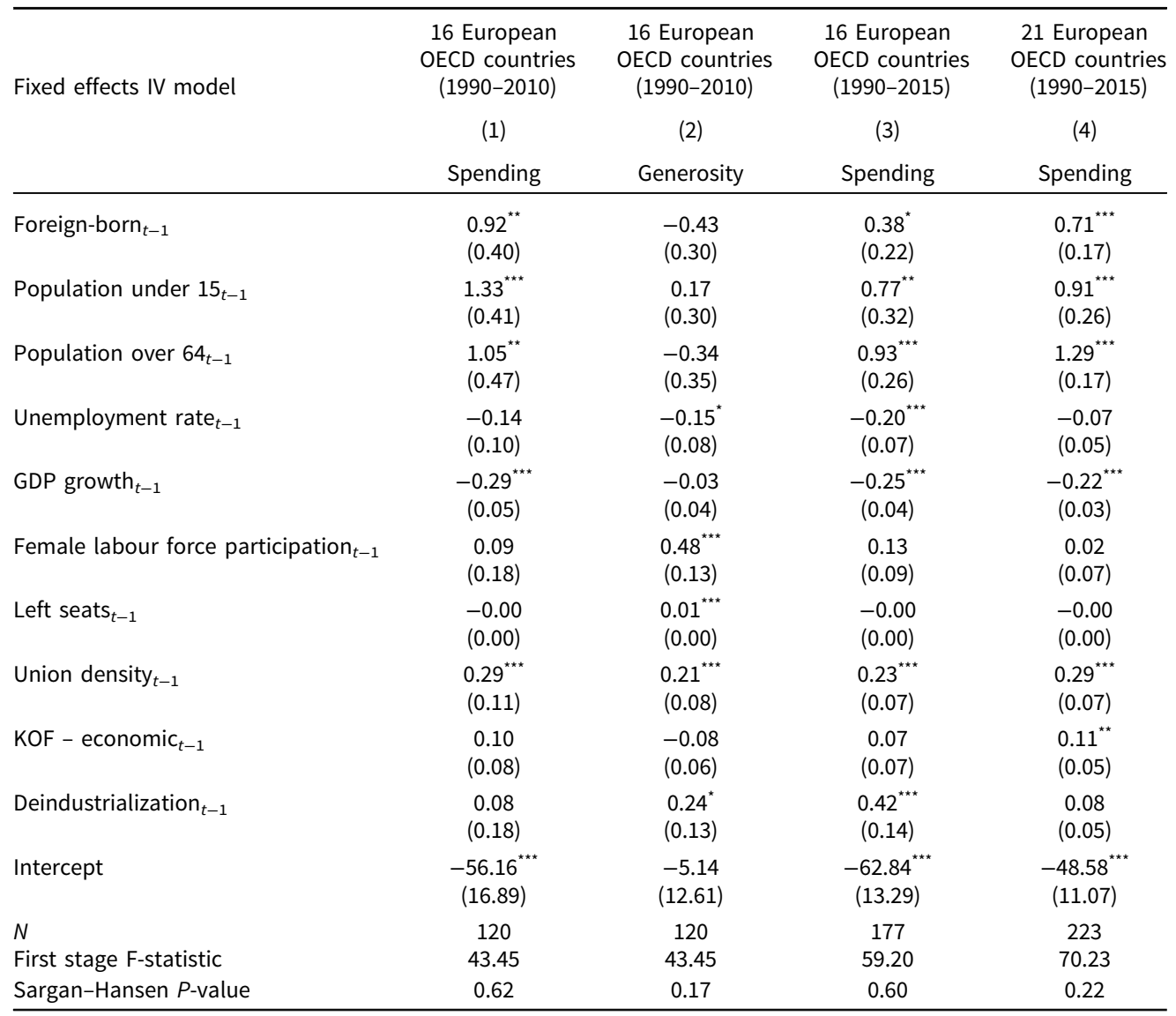

Standard errors in parentheses.

${ }^{*} P<.1,{ }^{* *} P<.05,{ }^{* \star *} P<.01$.

generosity index, then there is still no negative relationship between foreign-born and welfare generosity found. Moreover, after a number of tests were taken to check the robustness of the results, the headline findings remain stable. Consequently, there is no evidence to suggest that increasing immigration leads to the retrenchment of the welfare state. The results using the two indicators to express social welfare effort provide comparable results to authors who find support for the compensation hypothesis, thus providing an important contribution to existing knowledge on the political economy of immigration and welfare, as well as the wider political debate.

Nevertheless, by using macro-level aggregate indicators, it is difficult to pinpoint the causal relationship and future studies should be conducted in order to test the micro-level foundations of the compensation hypothesis for the 'human face' of globalization. In addition, while other studies have made efforts to disaggregate welfare spending into its component programmes, the independent variable foreign-born should also be disaggregated into different types of migration, (e.g. labour migration, family migration or asylum), in order to determine if different kinds of migration have different effects on social welfare effort. Finally, several theories suggest the importance of the skill level of migrants for having divergent influences on welfare state effort, steps should be taken to test this empirically in a macro-level study. However, there are practical limitations concerning the availability of data to take into consideration in order to make such an analysis possible. These areas for further research highlight certain limitations to this study. Also important is to note that the main 
analysis in this article is based on 16 European countries, over the time period 1990-2010. Therefore, outside of the sensitivity analysis already conducted, the results may not be generalizable to other parts of the world, other selections of countries or other time periods.

For policymakers, these results should help shed some light on a topic troubled by xenophobia, racism, and discrimination. The results that have been laid out here should contribute towards evidence-based policy making in the field of immigration and social policy. It is important to note that immigration does neither seem to be leading to a 'race-to-the-bottom' in Europe, nor should increasing immigration mean that policymakers need to look at benefits in neighbouring countries when drawing up their own welfare policies. Policymakers should aim to continue delivering welfare benefits and social protection schemes that work for improving social inequality and inclusion. This is particularly crucial for the successful integration of migrants into society, and as immigration numbers do not appear to be relenting, this will be fundamental for improving solidarity between diverse populations.

Acknowledgements. I would like to thank Olaf van Vliet, Kees Goudswaard, Koen Caminada, Alexandre Afonso, Susanne Schmidt, and Tobias Broich for their thoughtful and insightful feedback on previous versions of this paper. In addition, this study is a part of SOLID: Solidarity Under Strain and Interaction between Legal Systems (ILS 2.0).

\section{References}

Alesina, A. and E.L. Glaeser (2004), Fighting Poverty in the US and Europe : A World of Difference, Oxford: Oxford University Press.

Alesina, A., E.L. Glaeser and B. Sacerdote (2001), 'Why doesn't the United States have a European-style welfare state?', Brookings Papers on Economic Activity (2): 187-277.

Allan, J.P. and L. Scruggs (2004), 'Political partisanship and welfare state reform in advanced industrial societies', American Journal of Political Science 48(3): 496-512.

Armingeon, K., Wenger, V., Wiedemeier, F., Isler, C., Knöpfel, L., Weisstanner, D. and Engler, S. (2017), Comparative Political Data Set 1960-2015, Bern: Institute of Political Science, University of Berne.

Armingeon, K. and N. Giger (2008), 'Conditional punishment: a comparative analysis of the electoral consequences of welfare state retrenchment in OECD nations, 1980-2003', West European Politics 31(3): 558-580.

Boeri, T. (2010), 'Immigration to the land of redistribution', Economica 77(308): 651-687.

Burgoon, B. (2001), 'Globalization and welfare compensation: disentangling the ties that bind', International Organization 55(3): 509-551.

Burgoon, B., F. Koster and M. van Egmond (2012), 'Support for redistribution and the paradox of immigration', Journal of European Social Policy 22(3): 288-304.

Caminada, K., K. Goudswaard and O. Van Vliet (2010), 'Patterns of welfare state indicators in the EU: Is there convergence?', Journal of Common Market Studies 48(3): 529-556.

Cerny, P.G. (1995), 'Globalization and the changing logic of collective action', International Organization 49(4): 595-625.

Clasen, J. and N.A. Siegel (2007), 'Comparative welfare state analysis and the "dependent variable problem”, in J. Clasen and N. Siegel (eds.), Investigating Welfare State Change: The "Dependent Variable Problem" in Comparative Analysis, Cheltenham: Edward Elgar Publishing Limited, pp. 3-12.

Dreher, A. (2006), 'Does globalization affect growth? Evidence from a new index of globalization', Applied Economics 38(10): 1091-1110.

Esping-Andersen, G. (1990), The Three Worlds of Welfare Capitalism, Princeton: Princeton University Press.

Eurostat (2017a), 'EU citizens living in another member state - statistical overview', Available at: =https://ec.europa.eu/ eurostat/statistics-explained/index.php?title=EU_citizens_living_in_another_Member_State_-_statistical_overview\#Who_ are_the_most_mobile_EU_citizens.3F [Accessed 23 August, 2018].

Eurostat (2017b), 'Migration and migrant population statistics', Available at: http://ec.europa.eu/eurostat/statistics-explained/ index.php/Migration_and_migrant_population_statistics [Accessed 19 June, 2017].

Finseraas, H. (2008), 'Immigration and preferences for redistribution: an empirical analysis of European survey data', Comparative European Politics 6(4): 407-431.

Freeman, G.P. (1986), 'Migration and the political economy of the welfare state', American Academy of Political and Social Science 485: 51-63.

Friedman, M. (1999), “Question and Answer Session with Milton Friedman." Discussion at the 18th Annual Institute for Liberty and Policy Analysis (ISIL) World Libertarian Conference, San Jose, Costa Rica, August 20-22, 1999. 
Gaston, N. and G. Rajaguru (2013), 'International migration and the welfare state revisited', European Journal of Political Economy 29: 90-101.

Green-Pedersen, C. (2004), 'The dependent variable problem within the study of welfare state retrenchment: defining the problem and looking for solutions', Journal of Comparative Policy Analysis 6(1): 3-14.

Hays, J.C., S.D. Ehrlich and C. Peinhardt (2005), 'Government spending and public support for trade in the OECD: an empirical test of the embedded liberalism thesis', International Organization 59(02): 473-494.

Iversen, T. and T.R. Cusack (2000), 'The causes of welfare state expansion: deindustrialization or globalization?', World Politics 52(3): 313-349.

Jensen, C. (2011), 'Less bad than its reputation: social spending as a proxy for welfare effort in cross-national studies', Journal of Comparative Policy Analysis 13(3): 327-340.

Kropko, J. and R. Kubinec (2018), 'Why the two-way fixed effects model is difficult to interpret, and what to do about it', Social Science Research Network. Retrieved from https://ssrn.com/abstract=3062619

Kvist, J. (2004), 'Does EU enlargement start a race to the bottom? Strategic interaction among EU member states in social policy', Journal of European Social Policy 14(3): 301-318.

Lipsmeyer, C.S. and L. Zhu (2011), 'Immigration, globalization, and unemployment benefits in developed EU states', American Journal of Political Science 55(3): 647-664.

Magni-Berton, R. (2014), 'Immigration, redistribution, and universal suffrage', Public Choice 160(3-4): 391-409.

Mau, S. and C. Burkhardt (2009), 'Migration and welfare state solidarity in Western Europe', Journal of European Social Policy 19(3): 213-229.

Meltzer, A.H. and S.F. Richard (1981), 'Tests of a rational theory of the size of government', The Journal of Political Economy 89(5): 914-927.

Mummolo, J. and E. Peterson (2018), 'Improving the interpretation of fixed effects regression results', Political Science Research and Methods 6(04): 829-835.

Nannestad, P. (2007), 'Immigration and welfare states: a survey of 15 years of research', European Journal of Political Economy 23(2): 512-532.

Nickell, S. (1981), 'Biases in dynamic models with fixed effects', Econometrica 49(6): 1417-1426.

OECD (2017a), 'Migration - foreign-born population', Available at: https://data.oecd.org/migration/foreign-born-population. htm.

OECD (2017b), 'OECD Data', Available at: https://data.oecd.org/.

OECD (2017c), 'Social Expenditure Database (SOCX)', Available at: http://www.oecd.org/social/expenditure.htm.

Pierson, P. (1996), 'The new politics of the welfare state', World Politics 48(2): 143-179.

Plümper, T., V.E. Troeger and P. Manow (2005), 'Panel data analysis in comparative politics: linking method to theory', European Journal of Political Research 44: 327-354.

Razin, A., E. Sadka and P. Swagel (2002), 'Tax burden and migration: a political economy theory and evidence', Journal of Public Economics 85(2): 167-190.

Rodrik, D. (1998), 'Why do more open economies have bigger governments?', Journal of Political Economy 106(5): 997-1032.

Rueda, D. (2006), 'Social democracy and active labour-market policies: insiders, outsiders and the politics of employment promotion', British Journal of Political Science 36: 385-406.

Ruggie, J.G. (1982), 'International regimes, transactions, and change: embedded liberalism in the postwar economic order', International Organization 36(2): 379-415.

Scruggs, L. (2006), 'The generosity of social insurance, 1971-2002', Oxford Review of Political Economy 22(3): 349-364.

Scruggs, L. (2007), 'Welfare state generosity across space and time', in J. Clasen and N. A. Siegel (eds.), Investigating Welfare State Change: The "dependent Variable Problem" in Comparative Analysis, Cheltenham: Edward Elgar, pp. 133-165.

Scruggs, L., D. Jahn and K. Kuitto (2014), Comparative welfare entitlements dataset 2. version 2014-03, University of Connecticut \& University of Greifswald.

Scruggs, L. and J. Allan (2006), 'Welfare-state decommodification in 18 OECD countries: a replication and revision', Journal of European Social Policy 16(1): 55-72.

Soroka, S., et al. (2016), 'Migration and welfare state spending', European Political Science Review 8(02): 173-194.

Soroka, S.,R. Johnston and K. Banting (2006), 'Immigration and redistribution in a global era', in S. Bowles, P. Bardhan and M. Wallerstein (eds.), Globalization and Egalitarian Redistribution, Princeton: Princeton University Press and Russell Sage Foundation, pp. 261-288.

Starke, P. (2006), 'The politics of welfare state retrenchment: a literature review', Social Policy and Administration 40(1): 104-120.

Starke, P., A. Kaasch and F. Van Hooren (2014), 'Political parties and social policy responses to global economic crises: constrained partisanship in mature welfare states', Journal of Social Policy 43(2): 225-246.

Stichnoth, H. and K. Van der Straeten (2013), 'Ethnic diversity, public spending, and individual support for the welfare state: a review of the empirical literature', Journal of Economic Surveys 27(2): 364-389.

Taylor-Gooby, P. (2005), 'Is the future American? Or, can left politics preserve European welfare states from erosion through growing diversity?', Journal of Social Policy 34(04): 661. 
UN-DESA \& OECD (2013), 'World migration in figures', Available at: https://www.oecd.org/els/mig/World-Migration-inFigures.pdf [Accessed 31 August, 2017].

van Oorschot, W. (2013), 'Comparative welfare state analysis with survey-based benefit recipiency data: the 'dependent variable problem' revisited', European Journal of Social Security 15(3): 224-248.

Visser, J. (2016), ICTWSS database, version 5.1, Amsterdam: Amsterdam Institute for Advanced Labour Studies (AIAS), University of Amsterdam.

Walter, S. (2010), 'Globalization and the welfare state: testing the microfoundations of the compensation hypothesis', International Studies Quarterly 54(2): 403-426.

Walter, S. (2017), 'Globalization and the demand-side of politics: how globalization shapes labor market risk perceptions and policy preferences', Political Science Research and Methods 5(1): 55-80.

Wang, J. and O. van Vliet (2016), 'Social assistance and minimum income benefits: benefit levels, replacement rates and policies across 26 OECD countries, 1990-2009', European Journal of Social Security 18(4): 333-355.

\section{Appendix A - List of figures.}

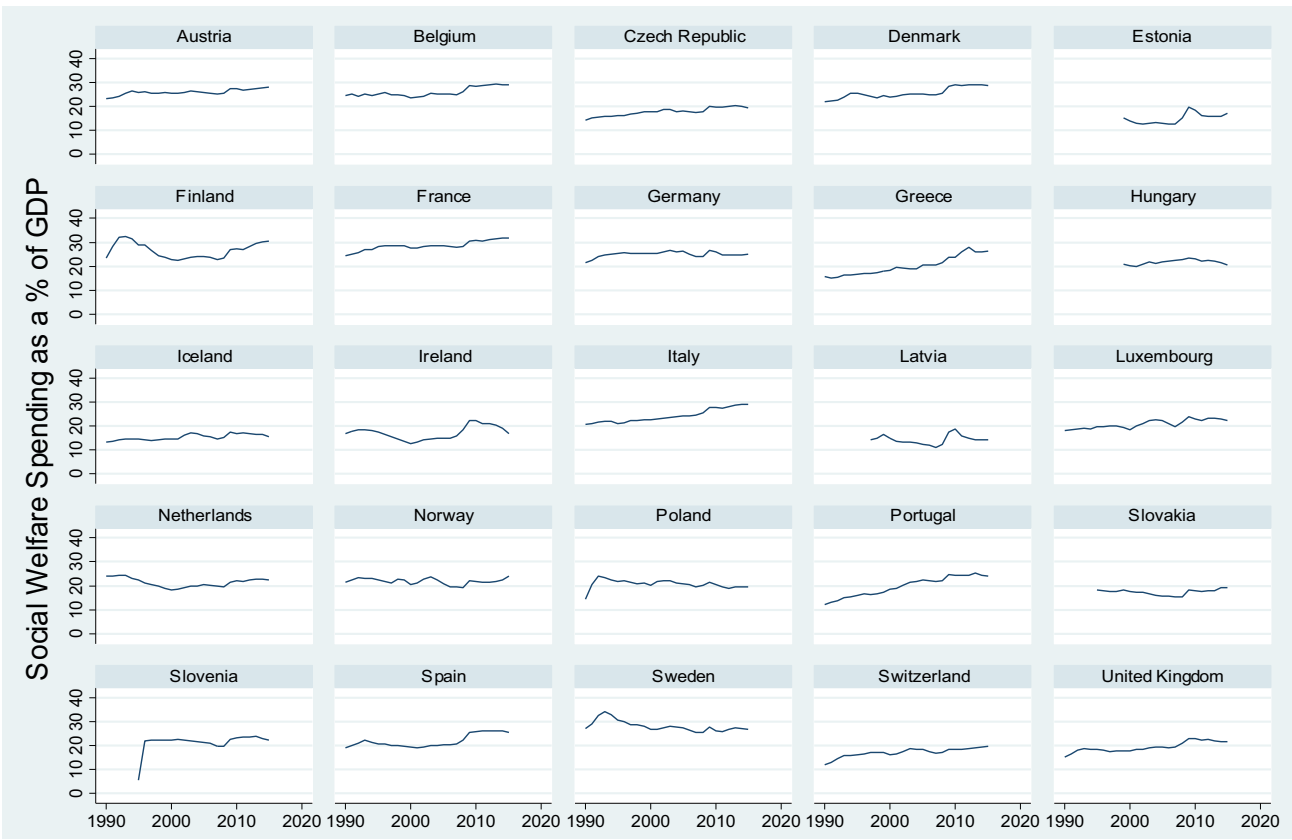

Figure A1. Social welfare spending as a percentage of GDP, over time. 


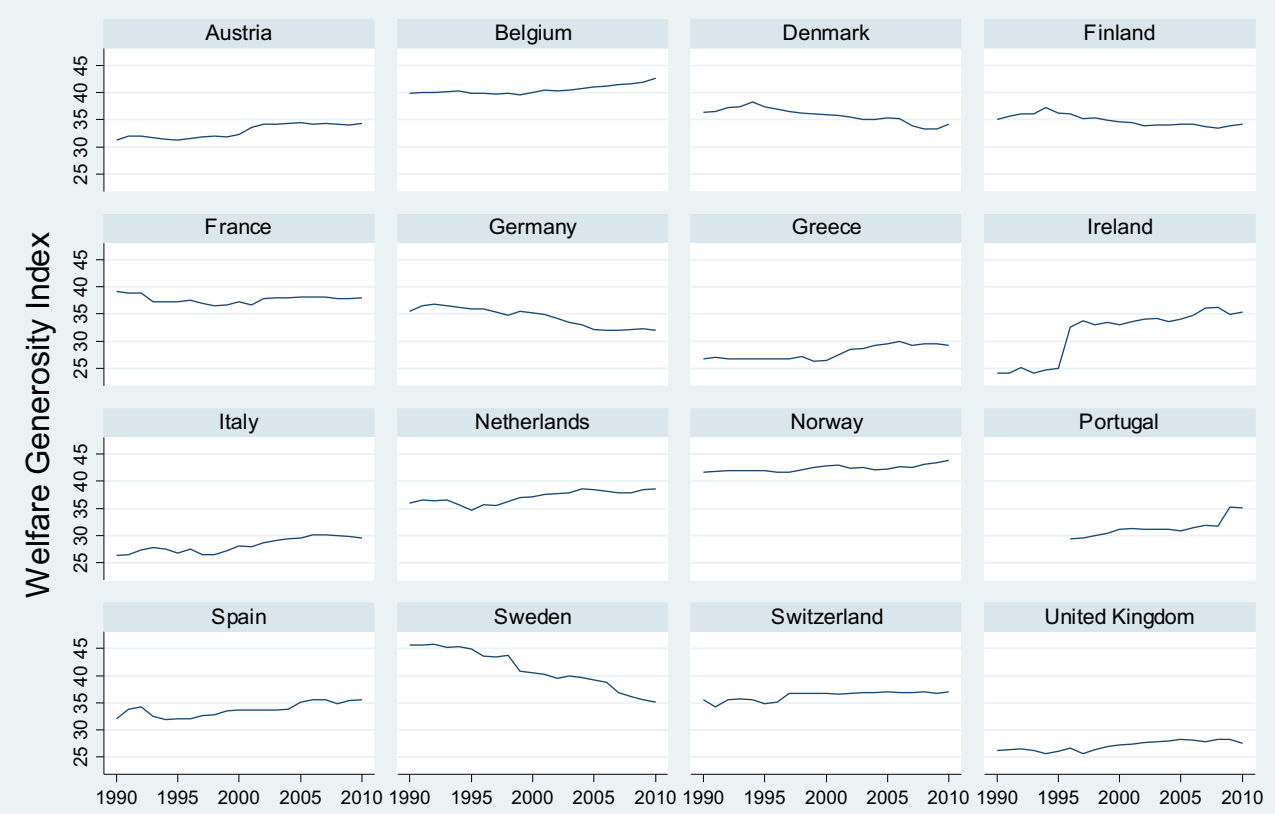

Figure A2. Total generosity index, over time.

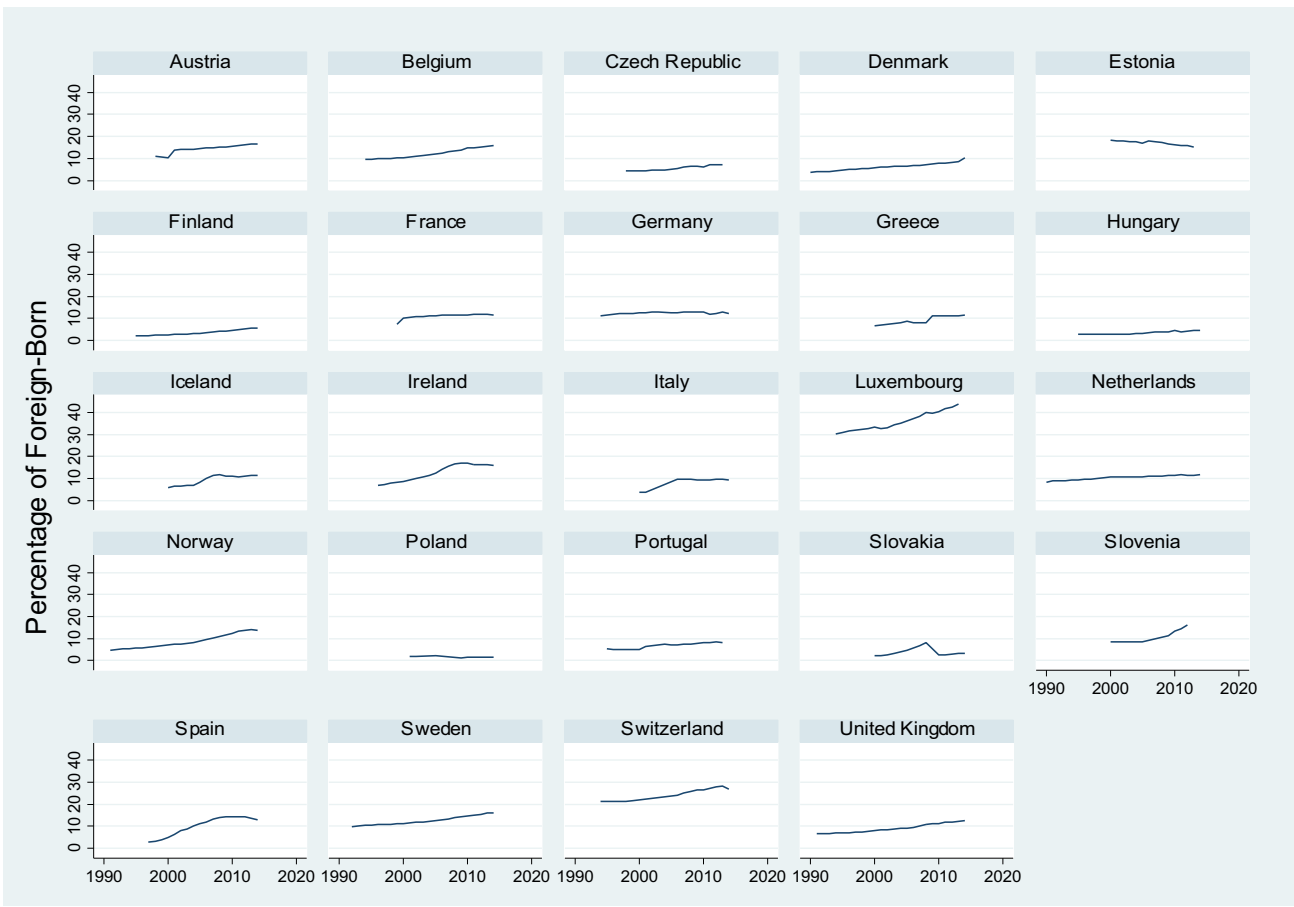

Figure A3. Foreign-born as a percentage of the total population, over time. 


\section{Appendix B - Phillips-Perron test.}

Table B1 Results of the Phillips-Perron test for spending

\begin{tabular}{lll}
\hline Country & $\mathrm{P}$ & \\
\hline Austria & 0.26 & Fail to reject the null of a unit root \\
Belgium & 0.86 & Fail to reject the null of a unit root \\
Denmark & 0.84 & Fail to reject the null of a unit root \\
Finland & 0.39 & Fail to reject the null of a unit root \\
France & 0.34 & Fail to reject the null of a unit root \\
Germany & 0.003 & Reject the null of a unit root \\
Greece & 0.51 & Fail to reject the null of a unit root \\
Ireland & 0.996 & Fail to reject the null of a unit root \\
Italy & 0.995 & Fail to reject the null of a unit root \\
Netherlands & 0.51 & Fail to reject the null of a unit root \\
Norway & 0.15 & Fail to reject the null of a unit root \\
Portugal & 0.22 & Fail to reject the null of a unit root \\
Spain & 0.96 & Fail to reject the null of a unit root \\
Sweden & 0.10 & Fail to reject the null of a unit root \\
Switzerland & 0.03 & Reject the null of a unit root \\
United Kingdom & 0.78 & Fail to reject the null of a unit root \\
\hline
\end{tabular}

Table B2 Results of the Phillips-Perron test for generosity

\begin{tabular}{lll}
\hline Country & $\mathrm{P}$ & \\
\hline Austria & 0.78 & Fail to reject the null of a unit root \\
Belgium & 0.999 & Fail to reject the null of a unit root \\
Denmark & 0.17 & Fail to reject the null of a unit root \\
Finland & 0.15 & Fail to reject the null of a unit root \\
France & 0.14 & Fail to reject the null of a unit root \\
Germany & 0.005 & Reject the null of a unit root \\
Greece & 0.83 & Fail to reject the null of a unit root \\
Ireland & 0.57 & Fail to reject the null of a unit root \\
Italy & 0.69 & Fail to reject the null of a unit root \\
Netherlands & 0.81 & Fail to reject the null of a unit root \\
Norway & 0.93 & Fail to reject the null of a unit root \\
Portugal & 0.97 & Fail to reject the null of a unit root \\
Spain & 0.63 & Fail to reject the null of a unit root \\
Sweden & 0.16 & Fail to reject the null of a unit root \\
Switzerland & 0.12 & Fail to reject the null of a unit root \\
United Kingdom & 0.69 & Fail to reject the null of a unit root \\
\hline
\end{tabular}

Cite this article: Fenwick C (2019). The political economy of immigration and welfare state effort: evidence from Europe. European Political Science Review 11, 357-375. https://doi.org/10.1017/S175577391900016X 